\title{
Cultural Tourism in Croatia after the Implementation of the Strategy of Development of Cultural Tourism
}

\author{
Damir Demonja* \\ Received: December 2012 | Accepted: February 2013
}

\begin{abstract}
The tourist potential of Croatia's cultural assets has been recognized and there is evidence of strong demand for such products amongst both domestic and international tourists. Croatia from the standpoint of offer, with picturesque settlements, rich and various history, historic urban and rural areas, and with tourism developed in the coastal area has good prerequisites for the development of cultural tourism and cultural-tourism products, and the Strategy of development of cultural tourism has been created in order to identify strategic measures (priorities and plan of activities), which should encourage the development of cultural-tourism products of Croatian tourist destinations in the entire country. Strategy is adopted in 2003, and its implementation started in 2004. After five years, in 2008, the first comprehensive research that refers to the changes and progress related to the development of the state of cultural tourism in Croatia was made. Consequently, this article presents and analyzes some results of that research, preceded by a short overview of the state of cultural tourism in Croatia, which includes the analysis of Croatian strategies of development of culture, tourism and cultural tourism, analysis the role of the state in cultural tourism and, finally, states the possible directions of further development of cultural tourism in Croatia.
\end{abstract}

Key words: Croatia, cultural tourism, strategy, implementation, results

\section{Introduction}

Ten years cultural tourism is trying to be one of the key determinants of development of Croatian tourism, and at the highest levels it has been given special attention. While cultural tourism is not a new concept in Croatia, in Croatian scientific and professional community are small publishing activities about him, and its effects are not evaluated properly. Croatian cultural tourism is rarely researched in scientific terms, the evaluations of Croatian culture and tourism resources are rare and there are still many problems which cultural tourism encounters. The reasons for this are the inadequate and not systematic inter sectoral cooperation of tourism and culture, insufficient numbers of the conducted research results of the measures after ending of their cycles and, in general, difficult possibility of obtaining the few

\footnotetext{
* Institute for Development and International Relations, IRMO, Ljudevita Farkaša Vukotinovića 2, HR-1000o Zagreb, Croatia; ddemonja@irmo.hr
} 
existing official data from government institutions. In order to obtain a somewhat actual picture of the state of cultural tourism in Croatia, in this article are presented Croatian culture, tourism and cultural tourism development strategies, which form the basis for the development of the Croatian cultural tourism. Connection and cooperation of tourism and culture sectors is very important, because no one successful strategy can create within only one sector, or one of tourism, or that of culture. The critical role of the state in cultural tourism is shown, which is not sufficiently regulated by law and regulations, although this area is no longer new in Croatia. It is evident that the sectors of tourism and culture in Croatia are not regulated by the principles of inter-sector approach, and it usually stays at a declarative level, but is presented that the state, through its institutions, regulating the development of cultural tourism in Croatia. Finally, the article analyze some of the results from the last conducted research of visitors attitudes and consumption of attractions and cultural events in Croatia, which reveals problems of cultural tourism in Croatia, and for solving them are proposed some directions.

\section{Literature overview}

Cultural tourism as a theme in Croatian literature has not analyzed sufficiently, and very rarely presented as an independent entity. As will show this brief overview of Croatian literature on cultural tourism, few texts individually deal with the topic of cultural tourism, and it is studied within the framework of some other types of tourism. Often the interest of researchers focused on the treatment of certain segments of cultural tourism such as historical towns, architectural heritage, sites and urban centers in the function of cultural tourism (Tourism, 3, 2002). Or researchers were focused on the analysis of development opportunities for heritage in the tourism sector, as well as for the entire community, and in what ways they can encourage the coordinated development of cultural tourism and revitalize the historic core of cities out of season (Čaušević and Tomljenović, 2003). One text, concisely, in English language, interpreted the terms of cultural tourism, cultural-tourism product and "cultural" tourists, listed and explained the reasons why it is necessary strategically develop cultural tourism, based on which is designed Croatian Strategy of development of cultural tourism, and what are their strategic priorities, measures and actions (Tomljenović, et al., 2004). The issue of cultural tourism in Croatia and countries of the European Union, the institutional network of cultural tourism in Croatia, the various phenomena associated with cultural tourism in Croatia and in some European countries, some of the projects that came to life in the Croatian cultural tourism offer, culture in the new market relations, festivalization of culture, the role of the festivals in cultural tourism, for example the Lace Festival, were also analyzed in several professional and scientific publications such as in conference proceedings "Ethnology and cultural tourism" (2006) and "The Lace Festivals and cultural tourism” (2006).

First book whose topic is cultural tourism in Croatia, is that by Jelinčić D. A. „ABC of Cultural Tourism“ (Jelinčić, 2008). Book presents the development of tourism in last decades of 2oth century and growing trend of cultural tourism development was separate analyzed. Author defined concept of cultural tourism, explained all fundamental notions and synthesized results of previous research. Structure, way of functioning and work of large international organizations in cultural tourism was analyzed as a starting point for a detailed treatment of state role in creating conditions for its development. Research part of the book 
focuses on analysis of cultural and tourist sectors in five European countries, results are compared with the situation in Croatia, and recommendations for creating cultural and tourism policy were outlined. It is the first example of an academic treatment of cultural tourism in Croatia, which is detected the optimal ways of potential evaluation of Croatian culture in tourism and theoretically analyzed the problems that exist in creating programs/projects of cultural tourism.

Synthesis of the existing research and results of cultural tourism in Croatia, compared with those of some European countries, with recommendations for its implementation in practice, in article named "Cultural Tourism in Croatia and Some European Countries", treated researchers Demonja D. and Jelinčić D. A. (Demonja, Jelinčić, 2008). It is a contribution to the scientific research of cultural tourism, which represents a quality base that can serve as a starting point for future research of the respective theme.

To Croatian public is available the first comprehensive research of tourist attitudes and consumption of cultural attractions and events in Croatia, which was conducted in 2008 (Tomljenović and Marušić, 2009). The aim of this research was to describe the segment of the demand for cultural tourism in Croatia, which is based on the profile of visitors of cultural attractions and events, their motivation and satisfaction with the visit, and establish a methodology of continuous research of visitors with the tendency that the cultural sector independently conducts research of its visitors. The research included 37 cultural attractions and events equally allocated in coastal and inland Croatian counties and sample of 2500 respondents/visitors of attractions and events. Research results revealed profile of cultural tourists, their attitudes about visited cultural attraction/event, as well as on Croatian cultural-tourism offer, then the characteristics of cultural tourists travel, and their consumption, which should serve as an adequate basis for making quality decisions regarding the development of Croatian cultural-tourism products and their promotion. Although the research conducted for the Croatian Ministry of Tourism, the most important institution at the state level that takes care of tourism, it is not known whether the obtained results are helpful in further development and application of the existing Strategy of cultural tourism in Croatia. The individual results of this research will be discussed more detailed below in the text.

\section{Methods}

Methods of researched theme consisted of:

I. collection and analysis of existing relevant literature and documents, and analysis of current circumstances relating to tourism and culture in Croatia,

2. collection and analysis of data, information and research of relevant institutions regarding tourism and culture (Ministry of Culture of the Republic of Croatia, Ministry of Tourism of the Republic of Croatia, the Croatian National Tourist Board), and

3. talks with participants of education for cultural tourism, which conducted the state institutions and private stakeholders since 2005 to 2010. 


\section{Discussion}

\section{Tourism and cultural tourism in Croatia}

\section{Tourism in Croatia}

According to the latest official data from the Central Bureau of Statistics of the Republic of Croatia, tourism in Croatia in 2010 recorded a successful season with a total of IO.6O4 million tourist arrivals and 56.4I6 million overnight stays (Statistical Yearbook of the Republic of Croatia, 2OII, 4I6). Perhaps the results of tourist traffic be better that still does not have restrictions such as, for example, limited accommodation capacities, especially in the category of hotel accommodation, there is still an insufficient number of high class accommodation, the lack of offers that would trigger a number of tourist arrivals in the pre-season and post-season, insufficient or inappropriate presented offer of additional contents, still existing infrastructural deficiencies particularly those of communal infrastructure, inadequate offer of goods and services that are still not at the level of competition particularly for the segment of consumers with greater purchasing power, and others. The above-mentioned limitations affecting the development of cultural tourism, particularly those relating to additional contents as well as supply of goods and services to consumers with greater purchasing power.

The largest travel market in Croatia in 2010 was Germany with I.58 million arrivals, followed by Italy (I.OI8 million), Slovenia (I.OI7 million), Austria (8IO OOO) and the Czech Republic (606 000) (Statistical Yearbook of the Republic of Croatia, 2OII, 4I7). An important tourist generating markets are Poland, France, Slovakia, Hungary, Netherlands and United Kingdom. At the top of scale, as in previous years, it is still Germany, because it is commonly Croatian market of mass tourism, but for the research of cultural tourism it is important for several years a large number of tourists from United Kingdom, France and the Netherlands, which are known as highly expressed cultural demands tourists.

As for the types of accommodation (hotel and restaurant) facilities in 2OIO the largest number of tourists stayed in the so-called collective accommodation facilities (hotels, villas, resorts, tourist apartments), 7.92I million, which further confirms strong survival of mass tourism in Croatia. A large number of tourists stay in private accommodation facilities (households, rooms, apartments, summer houses, rural households), 2.639 million, followed by camping sites, 44000 (Statistical Yearbook of the Republic of Croatia, 2OII, 42O). It should have on mind that a significant number of guests who come on holiday, is not recorded individually, so the statistics are incomplete. Also, the Central Bureau of Statistics does not specifically categorize the various other types of accommodation (private hotels, farm houses, etc.), which could be relevant to create an image on the profile of cultural tourists coming to Croatia.

Regarding the geographical diffusion, according to data from 2OIO, Istria County had the highest number of tourists (2.627.9I8), followed by Primorje-Gorski Kotar (2.I5I.II8), and Split-Dalmatia County (I.637.656). Zadar counts 97I 092 tourists, Dubrovnik 982619 and Šibenik-Knin County 634 6I4 (Statistical Yearbook of the Republic of Croatia, 2OII, 427) and these three counties have traditionally a large number of mass tourist type. Istria and Primorje-Gorski Kotar County offer a combination of coastal tourism and content tourism, where tourism policy is focused on diverse offer, which record a very large number of overnight stays, Istria I7.73I.88I and Primorje-Gorski Kotar I0.938.29I, compared to other destinations that are primarily kept mass type of tourism.

As far as travel organizing, the data show that a total of 10.604 million tourists registered in Croatia in 2OIO, 6.659 million came individually and 3.945 million organized (Tourism, 
2OIO, Statistical Reports, 2OII, 22-23), which confirms the presence of post-modern tourists, among which are cultural tourists who are organizing their journey by themselves.

Croatia is a traditional tourist-oriented country, and data on tourist traffic in recent years confirm that tourism has become an active generator of development of Croatian economy. The most important Croatian tourist product is still a "sea and sun vacation", in which conceptual design and development Croatia has a nearly century-old tradition, while all the other tourist products are extremely small scale. However, small scale tourism products are very important, because the trends in demand for cultural tourism in Europe and worldwide, as well as market research TOMAS, which in Croatia conducted by the Institute for Tourism, show that Croatia must use the international tourist demand, which is based on the increasing interest in cultural heritage and authentic products.

However, certain problems are detected, because foreign guests express dissatisfaction with:

- cultural offer and its diversity,

- cultural heritage marking/labeling,

- insufficient information offered by destinations as well as with their quality,

- organized excursions/trips offer, and

- shopping possibilities.

\section{Cultural tourism in Croatia}

Richness of tangible and intangible Croatian cultural heritage is a resource for the development of cultural tourism in all its forms: heritage tourism and UNESCO sites, museums, archaeological, rural and eco-ethno tourism. According to data I have collected in personal correspondence with the Croatian Chamber of Economy, Tourism Sector, in November 2OI2, visitors to all tourist attractions in Croatia has been growing steadily and according to the latest data from 2007 were 7.9 million visitors. By number of visitors in the leading position are Dubrovnik-Neretva County with 2.I million visitors, City of Zagreb with I.6 million, Krapina-Zagorje County with 930 IO4 and Istria County with 843923 visitors. Mentioned institution in the second quarter of 2008 conducted a research on the number of visitors to the main tourist sights and attractions, which included 139 museums and galleries. A total of 750354 visitors visited them, of whom 54\% foreign and 46\% domestic. The largest number of visitors in museums and galleries was in Dubrovnik-Neretva County (39I IO2), then the City of Zagreb (III 239) and Krapina-Zagorje County (44 427). The largest number of visitors to other sights and attractions was in the City of Zagreb (4I8 2I4), and then in Krapina-Zagorje, Osijek-Baranja, Dubrovnik-Neretva and Primorje-Gorski Kotar County.

Croatian cultural and tourist offer as a destination makes: autochthonous atmosphere of Mediterranean coastal cities and the uniqueness of undiscovered coastal ones, as well as the attractiveness of continental urban centers and traditional rural areas. The variety of natural and cultural heritage and impressive monuments under UNESCO protection (Plitvice Lakes, Šibenik Cathedral, Euphrasian Basilica in Poreč, the old towns of Trogir, Dubrovnik and Split with its Diocletian palace) are examples of the rich cultural heritage of the Croatian origin. In Croatia, there are 175 museums and collections with an impressive inventory of domestic and world heritage with 2.I million visitors per year (Statistical Yearbook of the Republic of Croatia, 2OII, 5OO).

The potentials of archaeological tourism are a great number of archaeological museums (according to data from 2009 were I8) and archaeological sites, which can develop into first class tourist attractions such as, for example, Vukovar (site Vučedol), Vinkovci (site Sopot), 
Krapina (site Hušnjakovo), etc., with the fact that on the Croatian soil leaving a trace almost all European and many Asian nations, which ranking Croatia among the world's richest archaeological areas.

Croatian cultural heritage is exceptionally valuable resource in the Croatian tourism offer, as evidenced by the fact that $69 \%$ of tourists during their stay participate in one of cultural events, although the main motivation for their coming in Croatia is the sea and sun. It should also keep in mind that the existence of heritage and cultural resources does not mean that they are cultural and tourism products.

Cultural tourism is a generator of sustainable development; it allows places that are not only tourists become an interesting to tourists as well as to the local population, by designed strategies that are based on local cultural and art resources. Cultural-tourism products, as key components of cultural tourism contributing to the enrichment of the image of destination, increase consumption, length of stay and tourist satisfaction, which ultimately contributes to the sustainable development of the city, i.e. region where these products are consumed. Finally, cultural tourism is a long-term competitive advantage of tourism as one of the most important economic sectors in Croatia.

\section{Defining the cultural tourism}

There is no single definition of the term cultural tourism, because it is complex, often used and in its understanding there are many differences. Differences in the definition of cultural tourism arising from the fact that the experts who engaged in it are taken into account only what is based on the resources they use. Although the concept of cultural tourism is in the circulation, it is often not clear to which it refers, as terms and area that it covers are quite mixed. Basically, the term cultural tourism is used for journeys that include visits to cultural resources, regardless of whether it is tangible or intangible cultural resources, and regardless of the primary motivation. In order to understand properly the concept of cultural tourism, it is necessary to know the definitions of a number terms such as, for example, culture, tourism, cultural economy, cultural and tourism potentials, cultural and tourist offer, and others.

In addition the term cultural tourism should be analyzed from the viewpoint of different scientific disciplines such as economic, tourist, cultural, organizational, and others. Do not hold of a deeper analysis of the scientific concept of cultural tourism, it can be stated that the cultural tourism is an activity of special interests, i.e. one of a selective forms of tourism development motivated by cultural and art resources, values and contents. In order to understand properly the term cultural tourism should be viewed from different viewpoints (economic, organizational, tourist, cultural, educational, marketing), because it will be the only way to achieve its articulated dimension, proper understanding and development implementation in a way that cultural resources are activated and placed into function for tourism development.

\section{Croatian strategies of development of culture, tourism and cultural tourism}

Croatia is among the few countries in Europe that has individual documents, i.e. strategies of development of culture, tourism and cultural tourism that showed the results of cultural-tourism sector research, conducted in 2003, in five European countries: United Kingdom, Netherlands, Finland, Cyprus and Italy (Jelinčić 2008, I83-256). The intention is not to enter into the details of each of the existing strategy, but attention will be given to key points that strategies proposed. 


\section{Strategy of Cultural Development of Croatia}

Strategy of Cultural Development of Croatia is an integral part of the Development Strategy of Croatia in the 2Ist century, which was created in 2OOI, where for the first time, but not in a satisfactory manner, treated cultural tourism. However, despite this, the document encouraged the research of cultural tourism in the field, monitoring the cultural statistics, correctly perceived the necessity of using Croatian, general and local, diversity as essential points of sale, and emphasized the necessary decentralization of culture including the development of local cultural tourism strategies.

A segment of cultural tourism within the Strategy was developed based on experience and perceived problems in the field, as well as on European and world knowledge in this area, because there was very small amount of statistical data. Since the Croatian cultural diversity at the time of making the Strategy has not yet been recognized as a tourism resource, the Strategy was aimed at proposing the use of Croatian cultural diversity, and national and local cultural resources as the key selling points. The main goals were to extend the season after summer, to encourage the development of small entrepreneurship, the necessity of decentralization of culture in order to increase income from culturally oriented tourist visits, all of which should result in a richer, more inventive and diverse cultural and tourism offer. Also, it is especially important that the Strategy emphasized inter and intra sectoral approach with the final goal of a quality culture and tourism offer, i.e. their products to a wider geographical cultural tourism market.

\section{Strategy of development of Croatian tourism to 2010}

Strategy of development of Croatian tourism to 20IO, designed in 2003, is now the last strategic document of development of Croatian tourism adopted at the national level and it goal is to create the framework for quality, modern and innovative tourism offer, which should increase competitiveness of Croatian tourism and capital investment markets. In the Strategy, special attention is directed to cultural tourism, which becomes increasingly significant part of tourist offer and one of modern types of the tourism (Strategy of development of Croatian tourism to 2OIO, 2OO3, 9-IO). Although rich and diverse, cultural offer in Croatia is not properly presented, and series of practical actions and measures can be used to increase quality of tourist offer. Furthermore, respect for cultural values and sites diversity is one of the factors to achieve longterm sustainability of tourism development. As one of the strategic objectives of the Strategy is listed a comprehensive development of tourist destinations, including the development of cultural resources, and the proposed measures for its achievement are:

I. to establish designated funds for cultural-tourism projects, which should be implemented by the Ministry of Culture and Ministry of Tourism, and

2. to target funds for cultural-tourism projects in professional initiatives in which local government units, local tourist boards, travel agencies and cultural institutions should participate (Strategy of development of Croatian tourism to 2OIO, 20O3, 32).

The goal of Strategy is that Croatia should base its tourist development on preservation of exceptional diversity of natural and cultural heritage and principles of sustainable development in planning a quality tourist offer. Strategy clearly states the importance of cultural tourism for creation of future tourism development in Croatia, and SWOT analysis highlights particular strengths, great potential of Croatian tourism, and rich cultural and historical heritage with world-recognized and protected locations. Culture is given a particular importance, especially within the framework of tourist destinations development. 
Significance of this document is in its clear attitude towards the importance of cultural tourism in Croatia, stressing that culture is a priority in all regions in determining the most important topics/themes of tourism products. The document emphasizes that culture is undoubted potential of Croatian tourism and a great tourism resource. According to the proposed strategic goals of development of Croatian tourism to 2OIO, and highlighted role of culture as one of the holders of the future tourism development, Ministry of Tourism of Republic of Croatia has commissioned the Strategy of development of cultural tourism.

\section{Strategy of development of cultural tourism}

Strategy of development of cultural tourism is designed by the Institute for Tourism from Zagreb in 2003. Strategy is based on the principles of consultations at national and regional levels, the organization and partnership of culture and tourism which together must contribute to the development of Croatian cultural-tourism products in cooperation with relevant ministries and local communities. Although Croatia has a rich cultural heritage, which is prerequisite for the development of cultural tourism, is still visiting small number of tourists primarily because of its culture, showing that Croatia is not recognized as a destination rich in culture. The aim of the Strategy was to respond to these challenges and make recommendations for the implementation of projects that would be part of a work program of Croatian National Tourist Board, an umbrella marketing organization for the promotion of all Croatian tourist offers.

The Strategy is based on a partnership of culture and tourism, which would allow marketing positioning of the Croatian cultural offers on domestic and foreign tourist market through travel arrangements based on the cultural attractions of individual destinations. This would allow financial profit to culture and tourism, increase the income of local communities and ultimately achieve greater tourist traffic at the state level.

Strategy defined the concept of cultural tourism and "cultural" tourists, analyzed domestic and foreign demand, Croatian cultural resources, institutions and events, marketing, human resources, finance and legislation, and sets goals, strategic priorities and actions important for development of Croatian cultural and tourist product. Strategic goal is to create a critical mass of well-presented, modern interpreted and professionally promoted cultural-tourism products, which enrich visitors' satisfaction, create an image of destinations rich in cultural-tourism offer, attract new market segments and stimulate domestic demand (Strategy of development of cultural tourism, 2003, I6).

Scheduled time of Strategy implementation was four years during which environment and infrastructure were created that encourages and directs the long-term development of cultural-tourism initiative in Croatia, raised the quality of presentation and interpretation of existing cultural resources and created the preconditions for the development of Croatia as a destination for cultural tourism. As for the creation of appropriate infrastructure, the Office for Cultural Tourism at the Croatian National Tourist Board is established, responsible for realization of set tasks (more about it further in text), and members of the Supervisory Board were elected who oversee and direct the initiatives of the Strategy. Then it was identified ways of funding cultural-tourism products development, and professional teams for the advisory and technical assistance in creating cultural-tourism initiatives/programs/projects/products were established, as well as those for education of the subjects of local and regional governments, institutions and individuals.

The Strategy has identified five strategic priorities:

I. create a positive environment that will foster the development of cultural-tourist products, 
2. establish organization system and intra sectoral partnership/collaboration,

3. raise the level of education, i.e. knowledge and skills necessary for development of high-quality cultural-tourism products,

4. raise interpretation standards, equipment and quality of cultural-tourism products, i.e. product development, and

5. improve the system of information flow, promotion and distribution of cultural-tourism products (Strategy of development of cultural tourism, 20O3, I8-34).

This Strategy was primarily aimed to create preconditions of systematic development of Croatian cultural tourism as a development priority of Croatian tourism, environments and infrastructure that effectively encourage the development of cultural-tourism initiatives and their promotion, and through systematic education form Croatia as a destination of high quality cultural-tourism image. Strategy covered a period of four years, and at the end of 2008 realization of following goals is expected:

I. cultural tourism became a priority strategic orientation,

2. there is a critical mass of human resources with knowledge and skills of development of modern cultural-tourism product,

3. established culture of partnership, strong organizational structure and a good flow of information,

4. secured stable sources of financing of development of cultural-tourism projects, and

5. created cultural-tourism products at local, regional and national level (Strategy of development of cultural tourism, 2003, 35).

If today we analyze whether and to what extent these goals are realized, then the following reveals. The greatest success was achieved with goals I and 4. Cultural tourism has become a priority strategic commitment thanks to existence, implementation and enforcement of the Strategy, and due to systematical educational plan designed for all of interested parties. Also a significant contributing factor has been satisfactory realization of organization/partnership, especially organization and work of the Office for Cultural Tourism at the Croatian National Tourist Board, and identification of ways of financing the development of cultural-tourism products. Goal 3 was slightly less accomplished. Although there is a firm organizational structure for carrying out of the Strategy, which has proven to be effective in implementation of government incentives and support for initiatives/programs/projects of cultural tourism, as well as a relatively adequate flow of information, still there is a lack of satisfactory culture of partnership. Above all, there is only declarative inter and intra sectoral cooperation among sectors, with only a minor number of known, in actual practice witnessed examples, and a lack of cooperation between state and private sector supported with real life examples. The realization of goals 2 and 5 has proven to be inadequate. There is still a lack of human resources with knowledge and skills necessary for development of modern cultural-tourism product, due to an inadequate number of those with expertise in cultural management, and because the realization of this goal should be considered to be a constant, continuous process. The 5 th goal can merely be given a passing grade as there is no evidence of an increasing number of examples of established cultural-tourism products at local, regional and national levels, which should have resulted from following implementation of the action plan designed in the Strategy of development of cultural tourism. Regarding mentioned, it will be necessary to study and evaluate all initiatives/programs/projects of cultural-tourism products financed by the state budget funds in this period and differentiate desirable model examples from other and to implement certain 
amendments, corrections, changes, and to give a new orientation for future implementation of the Strategy. After the adoption of the Strategy it has never been critically reviewed, discussed and evaluated, instead its implementation began immediately. The Strategy is ambitiously constructed, but in some parts it is incomplete and lacks precision, mostly because of a lack of participation of various profiles experts, from different departments/sectors in its design. This uncovers its insufficient interdisciplinary approach, although the Strategy itself supports this approach in order to achieve its priorities, tasks and objectives, while, finally, the Strategy has not realized one of its priorities, and that is establishment and maintenance of inter and intra cooperation among sectors.

\section{The role of the state in the development of cultural tourism in Croatia}

Insufficient cooperation between the sectors of culture and tourism is present in the research of Croatian cultural tourism and tourism. Cultural-tourism product is complex and it requires an interdisciplinary approach, however, due to the disorganization of the system still lacks proper co-operation between the sectors of culture and tourism. Strategy of development of cultural tourism in Croatia defined the role of government in the sectors of culture and tourism, which should be actively involved in both sectors. As key state institutions for the development of cultural tourism in Croatia are identified the Ministry of Culture, Ministry of Tourism and the Croatian National Tourist Board.

Ministry of Culture of the Republic of Croatia its scope of work performs in seven directorates and two independent departments (http://www.min-kulture.hr/default.aspx?id=46I6). Each directorate is exclusively focused on jobs in their scope, rarely linking activities of two or more sectors, while cooperation between ministries (such as with the Ministry of Tourism) is practically non-existent. Recent examples of cooperation between the Ministry of Culture and Ministry of Tourism are reflected in the program "Under Ancient Roofs", designed to protect the old buildings of traditional architecture, which renews the old complexes in order to encourage small family hotel business. Or, "The Museum of Croatian Tourism" in Opatija, opened in November 2007. A lack of directorate for cultural tourism is noted, as well as forms of direct funding from the Ministry of Culture for cultural tourism initiatives/programs/projects. Usually cultural tourism initiatives are adjusted to the activities of particular directorate, as this is the only way to compete in public tenders for allocation of Ministry of Culture funds. While some of Ministry's directorates could take part in cultural tourism, such as the Directorate for Cultural Heritage Protection or Directorate for Cultural Development, this is not the case, since it only deals with static aspects of heritage. Further problem is seen in the lack of experts within the framework of the existing directorates, which would focus on cultural tourism. For now, Ministry of Culture annually invests more than IOO million Kuna ( $\approx \mathrm{I} 3$ millions $€$ ) in historic buildings that are also tourist destinations, such as examples of restoration and revitalization of Ilok and Vukovar through the program "Vukovar-Vučedol-Ilok", or already mentioned projects of reconstruction of traditional houses, in cooperation with the Ministry of Tourism, which also includes restoration of traditional farm buildings (mills, blacksmith, and so forth) (http://www.min-kulture.hr/default. aspx?id=IOO), organizes and promotes exhibitions outside Croatia (for instance "Croatian Apoxyomenos" in Florence, Italy, and "Seamanship on the Croatian Adriatic" in Barcelona, Span), while there are no tenders dedicated exclusively to cultural tourism.

Within the Ministry of the Sea, Tourism, Transport and Development of the Republic of Croatia (2004-2007), today Ministry of Tourism of the Republic of Croatia, a special seg- 
ment of administrative and other affairs related to tourism policy of the Republic of Croatia is performed within three directorates. Cultural tourism was the responsibility of the Directorate for Selective Forms of Tourism and their Department for Selective Forms of Tourism and Territorial Tourism Policy. Main tasks of that department were the following: proposing concepts and development policies of cultural tourism, proposing acts, regulations and measures for development and promotion of cultural tourism, as well as financing cultural tourism initiatives, programs and projects through public tenders (Demonja, 2006; 2006a). Today's Croatian Ministry of Tourism, according to data available to the public, consists of five directorates and one independent department, and in cultural tourism is engaged Directorate for Distinctive Select and Continental Tourism (http://www.mint.hr/default.aspx?id=7I6). Since 2005, the Ministry of Tourism of the Republic of Croatia for the development of cultural tourism granted supports and subsidies through program „De minimis aid grant programs without recurrence“. That program has been subsidized from 2005, i.e. 2007. Program for encouraging protection, reconstruction and inclusion of cultural and natural heritage into tourist offer in touristic underdeveloped areas, „Heritage in Tourism“, has been subsidized since 2005, while the other two programs: the Program for encouraging development of theme tourist routes in Croatia, „Theme Routes”, and the Program for encouraging and improving production and sales of souvenirs, „Original Souvenir“, have been subsidized since 2007 .

The last available official data for mentioned program are from 2009. After that year, no any data are available, and they cannot be obtained for publication and commenting even through the official channels. After 2009, all these programs are still active and state funds are allocated for them through public tenders and are issued once a year on the web pages of the Ministry of Tourism of the Republic of Croatia.

„Heritage in Tourism“ is a program that gave extraordinary results particularly in development of continental tourism, and from 2005 to 2009 co-financed 595 projects with the total amount of 3.556.056,89 Euro (Table I). 92\% of the projects were realized in the continental and coastal hinterland. With the implementation of these projects has been revived economic activity such as the increased number of tourist services providers in underdeveloped tourist areas, reconstruction of traditional facilities made possible the revival of ancient arts and crafts, and open new sales channels of domestic products and services. Heritage preservation encourages sustainable development, as many buildings of architectural heritage (folk architecture, mills, smitheries, and others) have been saved from further deterioration through new tourism purposes. Better protection of natural heritage was realized by co-financing the educational trails, viewpoints and observation points in protected areas/ regions.

The program "Theme Routes" that was initiated in 2007, aimed at better recognition of Croatia in whole as a diversified tourist country, raised interest and decision in travelers/day trippers to take a short break, circular trip, short holiday or combined holiday/summer holiday by visiting continental and Adriatic hinterland destinations, encouraged foreign tourists/ travelers already staying at a famous tourist destination or on circular trip to explore theme routes and less familiar tourist destinations in order to enlarge consumption and create thematically integrated and organized tourist attractions throughout the year by connecting natural, cultural and historical heritage of Croatia. From 2007 to 2009, there were I82 projects within the Program, which spent I.37I.222,07 Euro in total (Table I).

The same year began program „Original Souvenir" aiming at reliving the production of traditional and artistic crafts, encouraging additional activities (the production of homemade 
product - souvenir), confirming values of unique handmade production, encouraging the creation of reproductions, redesigns and new designs of products, protection and preservation of heritage in utilizing traditional techniques and materials. From 2007 to 2009, there were 278 projects in total amounting to 704.993,42 Euro (Table I).

Table 1. Funding the programs "Heritage in Tourism", "Theme Routes" and "Original Souvenir" by the Ministry of Tourism of the Republic of Croatia in total numbers/amounts per program from 2005 to 2009

\begin{tabular}{|l|l|r|r|}
\hline Year & \multicolumn{1}{|c|}{ Program name } & Total number of programs & \multicolumn{1}{c|}{ Total amount in Euro* } \\
\hline $2005-2009$ & Heritage in Tourism & 595 & $3.556 .056,89$ \\
\hline $2007-2009$ & Theme Routes & 182 & $1.371 .222,07$ \\
\hline $2007-2009$ & Original Souvenir & 278 & $704.993,42$ \\
\hline Total & & 1055 & $5.632 .272,38$ \\
\hline
\end{tabular}

*1 Euro = approximately 7,61 HRK

Source: Ministry of Tourism of the Republic of Croatia, November 2012

It should be noted that the Ministry of Tourism has commissioned the Strategy of development of Croatian tourism until 2OIO, which clearly indicated different, quality relationship with culture and tourism. Also, it commissioned the Strategy of development of cultural tourism, a key document which detects cultural tourism as a strategic orientation of Croatian tourism and is oriented to enrichment of the tourist product, extension of season, increasing consumption, attracting higher spending market segments, with holidays rich in activities. These two documents show clear and articulated position of the state towards cultural tourism, and classify Croatia in a group of rare countries, which have a state strategy for cultural tourism (Jelinčić, 2008, 303-3I4).

If we evaluate the success of tourism department within the framework of the ministries whose part was, i.e. as an independent state institution, in the field of cultural tourism, it is evident that this is a continuous and relatively abundant activity relating to the financing of cultural and tourism initiatives, programs and projects through public competitions. Funds intended for cultural tourism each year is increasing, and from 2005 to 2009 (data for $20 \mathrm{OO}$ and 2OII at the time of writing this article were not available) awarded a total of 5.632.272,38 Euro for IO55 projects (Table I).While diligently in the award of state funds or grants for initiatives, programs and projects of cultural and tourism initiatives, the Ministry of Tourism has not made their database, which was the basis for critical evaluation. Also, a large number of underlying projects is not known to the public, nor conducted systematic information about them. Therefore, the subject of future research should be a critical analysis of all projects financially supported with state funds, to determine how many of them come to life as cultural and tourism products, as follows by the Strategy of development of cultural tourism framework.

It should be emphasized once again that Croatia is one of the few European countries where there are state incentives for cultural tourism, which are awarded through public tenders, through the leading national organization. However, it should be set aside failure concerning to insufficient perseverance in the realization of intra and inter sectoral cooperation particularly with the Ministry of Culture. There are no specific data indicators, which would confirm the cooperation of ministries of culture and tourism in proposing and evaluating programs and finding funding sources for the purpose of encouraging and expanding cultural development initiatives, and should be more strongly insist on the establishment of future cooperation.

Croatian National Tourist Board is the national tourist organization founded for creation and promotion of Croatian tourism identity, its promotion at home and abroad, as well 
as raising the overall quality of Croatian tourism offer (http://business.croatia.hr/en-GB/ Croatian-national-tourist-board). Based on the Strategy of development of cultural tourism, Croatian National Tourist Board founded the Office for Cultural Tourism, with the intention of presenting Croatian cultural heritage to tourists in an acceptable and interesting way, and of creating cultural-tourism products. The Office for Cultural Tourism main tasks are a systematic encouragement, development and coordination of development initiatives of cultural-tourism products and its basic goals are to: create image of the destination rich in meaningful and substantial cultural-tourism offer, enrich satisfaction of existing visitors, stimulate consumption, extend the season and encourage off-season demand, attract new market segments, and stimulate domestic demand (Sršen, 2006, I7).

Establishment of the Office for Cultural Tourism shows concrete state involvement in understanding cultural tourism. Role of the Office for Cultural Tourism should be managerial; it should coordinate all Croatian cultural and tourist projects, their promotion, and should cooperate with the ministries of culture, tourism and Croatian National Tourist Board. However, its most important task is to foster the creation of cultural-tourism products. For this purpose, each year the Office finances projects and events with a modest amount of about I60.000,OO Euro. The evaluation of the Office's work will show if it has been successful in the realization of this demanding task. It appears, however, that the Office uses its possibilities insufficiently. First of all, cooperation with above mentioned ministries should be stronger, especially in developing non-existent but necessary legal regulations in the field of cultural tourism. This is especially important because existing acts do not regulate common cultural tourism sector, but each of them separately, while opportunities in the field show the necessity of linking cultural and tourism sector.

According to the foregoing, the framework of cultural tourism in Croatia is relatively good set with the Strategy of development of cultural tourism, and attention is focused on the implementation of coordination of the tourism sector with other sectors, i.e. departments that are associated with it, especially with those cultural. Strategy of development of cultural tourism, which clearly defines the role of the state in cultural tourism, guided by the wish for better organization of the cultural tourism according to World Tourism Organization trends and opportunities on the tourism market in Croatia. It particularly supports the need for improved coordination of culture and tourism departments, not only at the state level, but also at the local level, that is, for now, is still inadequate. Also, legislation is necessary to define certain aspects of cultural tourism, such as, for example, those physical, then the standards, monitoring, revision system, and more.

\section{Research of cultural tourism in Croatia}

The last research of cultural tourism in Croatia was conducted in 2008 (Tomljenović, Marušić, 2009). The aim of this research was to collect data on the characteristics of tourism demand and consumption of cultural visitors to cultural attractions and events in Croatia, for which was chosen 37 cultural attractions: I6 cultural-historical sights, 9 museums and galleries and I2 events, equally allocated in coastal and continental counties in Croatia.

The interest of this research was to find out the motivation and the satisfaction of the visit to cultural attractions/events and travel characteristics of cultural tourists. With regard to attitudes about visited cultural attraction/event cultural tourists expressed a very low level of satisfaction regarding the availability of information on attraction/event prior to the departure time 
and the quality of marking/labeling attractions/events (signalization) on the roads. Even $46 \%$ cultural tourists for more than a year in advance collects information about the attraction/ event, and 2I\% use the Internet as an information source, and then printed promotional materials (I8\%). Intermediate level of satisfaction was expressed by cultural tourists for the availability of information about the attraction/event in the area they are located, their quality and availability. The vast majority is satisfied with the visit: for the $48 \%$ visit has surpassed expectations, while for the $47 \%$ is in accordance with expectations. As for services, medium degree of satisfaction was evaluated offer of souvenirs, which is indicative considering that in the framework of the Strategy, from 2007 to 2009, within the program "Original souvenir" conducted by the Ministry of Tourism, realized 278 projects for which a total of 704.993,42 Euro were allocated with the intention of improving the quality of Croatian souvenirs offer. This rating indicates that the focused and clearly defined program may not always be successful, which once again calls for the urgent critical evaluation of projects financed by state funds.

The attitudes of cultural tourists on Croatian cultural offer showed that 5I\% of visitors increased interest in visiting the same or similar attractions/events. Satisfaction with visiting cultural attraction/event has a positive impact on the wish to visit the same or similar attractions during their stay in the destination. For $49 \%$ of visitors is increased interest to attractions/events on the continent (on the coast 53\%), while for $47 \%$ of visitors in continental Croatia interest is the same (on the coast 43\%). Most foreign cultural tourists identified Croatia with a rich cultural and historical heritage (84\%), unique customs, traditions and gastronomy (72\%) and with the richness of museums and galleries (71\%). Between $50 \%$ and $60 \%$ of tourists identified Croatia with festivals and events, rich cultural and artistic life and a pleasant destination for travels motivated by culture. These attitudes of tourists tied for Croatia's cultural offer confirm that it has adequate quality, which is certainly helped the Strategy that define goals, tasks and actions that must be followed to increase the quality of cultural-tourism products and attractions/events.

Finally, the results of the popularity of Croatian cultural-tourism offer (travel characteristics of cultural tourists) have shown that visitors most visit cultural and historical sights and attractions (64.9\%), churches and monasteries (64.I\%), museums and galleries (58.6\%), festivals (42.2\%), thematic routes and roads (33.2\%), musical events and shows (32.5\%). On the continent is the higher popularity of festivals, which was shown by $65 \%$ of visitors, while on the coast $42 \%$ of visitors are engaging in festivals. In Croatia, $20.4 \%$ of tourists coming on vacation with the aim of exploring the culture, and $26.4 \%$ of tourists as the main reason for traveling states visit cultural attraction/event. Thus, there are a large percentage of visitors that can be considered as targeted, culture motivated tourists who travel specifically for visits to cultural attraction/event or they are on vacation motivated by culture.

Above presented research is the first comprehensive study of visitors' attitudes and consumption to cultural attractions and events in Croatia after eight years of implementation of the Strategy of development of cultural tourism. Collected results in certain segments show the effectiveness/ineffectiveness of the realization of certain tasks and actions prescribed by Strategy. They can serve as a basis for making future decisions regarding the development of cultural-tourism products and their promotion. Also, this research could serve as a basis for continuing research of demand for cultural-tourism products in Croatia. This is important considering that the state funds granted by the Ministry of Tourism and Office for Cultural Tourism must be directed to the cultural-tourism products which tourists looking for, as well as to those products that would attract new cultural tourists. 


\section{Directions for future development of cultural tourism in Croatia}

Despite the existence and implementation of the Strategy of development of cultural tourism, cultural tourism in Croatia is still burdened with a certain number of problems, and the most obvious are: lack of recognizable cultural-tourism products, lack of cooperation between the sectors of culture and tourism and inadequate promotion. The existence of these problems in practice has confirmed the results of the last research on cultural tourism in Croatia, which are previously discussed.

Further development of cultural tourism in Croatia should be viewed in the context of cultural tourism as a phenomenon which goal is motivating people to travel and to meet with local cultural values, which enables them to meet better the different cultures. The basis for this development is the existence of articulated and applicable strategies for sustainable development; therefore it is necessary further long-term planning and designed management, which must define the long-term goals and short-term development priorities. Croatian cultural potentials are numerous, but so far the development results are modest in relation to opportunities, because of the lack of comprehensive planning and clearly defined objectives and priorities for development, particularly on regional and local levels. Therefore, the local levels or community should necessarily have an even greater role in the further development of cultural tourism in Croatia, because local authorities have the most direct interest in the development of cultural tourism. In this context, it is very important an effective and concrete inter sectoral connection and cooperation between the ministries, that is, for now, mainly declarative. Sectors are still working for themselves, hardly communicate and do not have a permanent and well-coordinated relationship which is a result of years of separate sectoral development. Therefore, in the field of cultural tourism it is necessary further insistence on cooperation between the sectors, which is one of the preconditions for the development of regional and local communities in ways that will enable the development of local initiatives.

In order that the Croatian cultural tourism comes to life in an appropriate manner, among other things, it would be necessary to do the following tasks:

- systematically educate coordinators of projects on cultural heritage management, because only a multidisciplinary trained professionals can activate one cultural and tourist potential culturally, educationally and commercially,

- reduce or eliminate the centralization and bureaucratization of procedures for the implementation of a cultural-tourism project, changing the regulations and effective administration,

- $\quad$ systematically raise the level of awareness and knowledge of local people to new cultural and tourism projects,

- encourage the use of new, innovative ways of financing of cultural and tourist projects: market, entrepreneurship, sponsorship,

- direct the development of high quality and distinctive local cultural and tourism products,

- encourage the existing Office for Cultural Tourism to provide better and more aggressive promotion of cultural-tourism projects taking into consideration the IT infrastructure and a strong and constant presence in the area of virtual tourism, which corresponds to the present time,

- continue to strengthen the state's role in cultural tourism, which should continue to provide the conditions for the development of cultural tourism by integrating promotion programs, adapting legislation, coordinating the existing projects and 
encouraging new ones, developing cooperation with local authorities, undertaking systematic market research in the field of culture and tourism, and obtaining results use to correct the existing steps of development of cultural-tourism products, and

- minimize the impact of the politics, although it is impossible to eliminate completely since the political interests are often before the interests of the user/visitor. Considering that the politics generally does not plan a long term, and then the results are visible at the end of the political mandate, which new political option use only if achieved results correspond to their interests.

Croatia has set a good base for the development of cultural tourism, because it has strategic documents relating to tourism, culture and cultural tourism, which are defined by the ministry to deal with it, and established Office for Cultural Tourism. Although the Strategy provided basis and recommendations for the beginning of the systematic functioning of cultural tourism, it has not offered a concrete time-defined action plan, which should develop as soon as possible within the Office as a national umbrella organization of cultural tourism "covers" an insufficient number of activities. Until now, the work of the Office concentrated only on financing the projects in small scale, and education and informing in the field of cultural tourism, while the Office does not deal with the coordination of local and regional projects on behalf of the state. Overcoming of the aforementioned disadvantages and with new, upgraded insights based on experiences gained by the application of the Strategy of development of cultural tourism, as well as on the results of research visitor's attitudes and consumption of attractions and cultural events in Croatia, Croatian cultural tourism has a perspective, especially on the international tourism market.

\section{Conclusion}

With the Strategy of development of cultural tourism, establishing the Office for Cultural Tourism and with its activities and the activities of the Ministry of Tourism at the national level, cultural tourism is defined as one of priorities of Croatian tourism. The implementation of the Strategy under the operational activities of the Office for Cultural Tourism and especially with regional and local development stakeholders, preconditions of systematic development of cultural tourism in Croatia will be created. It should benefit both tourist and cultural sector. The overall destination image should be raised, which would retain existing guests, stimulate their activity and consumption during their stay, encourage extension of their stay in the destination and extend the season. The quality destination image would attract other visitors. It is also necessary to use cultural assets in a sustainable manner which would increase the revenue due to the increase of a number of visitors.

Although in implementation of eight years, Strategy of development of cultural tourism has shown some problems. The Strategy lacks interdisciplinary approach, which has impacts on its implementation. One of the key problems is articulation and organization of all organizations, bodies and agencies that should participate in the implementation of the Strategy, which is worrying and still, in greater extent, present and unsolved problem. Although since 2005 the state budget for cultural tourism has increased, recognizable cultural-tourism products have not been developed; therefore it is necessary to detect specific problems regarding this issue. 
For effective implementation of the Strategy, it is necessary to evaluate critically actions that had been carried so far, as well as to evaluate inter and intra sectoral cooperation, since it is essential that all stakeholders of the Strategy actively cooperate as equal partners in all processes of its implementation. This is substantial because Croatia has opted for the longer term strategic development of cultural tourism, whose ultimate goal is the well-developed cultural-tourism products.

\section{References}

Croatian National Tourist Board. General Information. http://business.croatia.hr/en-GB/ Croatian-national-tourist-board. (IO/II/I2).

Čaušević, S., Tomljenović, R. (2003). World cultural heritage, tourism and revitalization Euphrasius Basilica in Poreč. Tourism 5I/4, 289-398.

Demonja, D., Jelinčić, D. A. (2008). Dossier: Cultural Tourism in Croatia and Some European Countries. Croatian International Relations Review - CIRR, XIV, 5O/5I, I-I5.

Demonja, D. (2006). Institutional Network of Cultural Tourism. In T. P. Leš \& T. Pletenac (Eds.) Ethnology and Cultural Tourism, II-I5. Faculty of Humanities and Social Sciences, University of Zagreb, Department of Ethnology and Cultural Anthropology, Zagreb.

Demonja, D. (2006a). The role of the Directorate of Tourist Boards and Selective Forms of Tourism of the Ministry of the Sea, Tourism, Traffic and Development of the Republic of Croatia in Cultural Tourism. In T. P. Leš (Ed.) Lace Festivals and Cultural Tourism, 69-80, Tourist Board of the City of Lepoglava and City of Lepoglava, Lepoglava.

Jelinčić, D. A. (20O3). ABC of Cultural Tourism, Meandar, Zagreb.

Ministry of Culture of the Republic of Croatia. Home. http://www.min-kulture.hr/default. aspx?id=46I6. (I2/II/I2).

Ministry of Culture of the Republic of Croatia. Projects of the Ministry. http://www. min-kulture.hr/default.aspx?id=IOO. (IO/II/I2).

Ministry of Tourism of the Republic of Croatia. Contacts. http://www.mint.hr/default.aspx?id=7I6. (I2/II/I2).

Sršen, M. (2006). The Role of the Croatian National Tourist Board in Cultural Tourism. In T. P. Leš \& T. Pletenac (Eds.) Ethnology and Cultural Tourism, I7. Faculty of Humanities and Social Sciences, University of Zagreb, Department of Ethnology and Cultural Anthropology, Zagreb.

Statistical Yearbook of the Republic of Croatia. (2OII). Croatian Bureau of Statistics, Zagreb. Strategy of development of Croatian tourism until 2OIO. (2003). Ministry of Tourism of the Republic of Croatia, Zagreb. Available at http://www.mint.hr/UserDocsImages/Strategija\%2Ohrvatskog\%2Oturizma\%2O-\%2Ofinalna\%2Overzija.pdf. (4/II/I2).

Strategy of development of cultural tourism: From tourism and culture to cultural tourism. (2003). Institute for Tourism, Zagreb.

Tomljenović, R., Marušić, Z. (2009). Attitudes and Consumption of Cultural Attractions and Events in Croatia: Tomas Cultural Tourism 2008, Institute for Tourism, Zagreb.

Tomljenović, R., Marušić, Z., Weber, S., Hendija, Z. and Boranić, S. (2004). Croatian Cultural Tourism Policy: Strategic Development. Tourism, 52/4, 36I-373.

Tourism, 3, 2002.

Tourism, 2OIO. Statistical Reports. 2OII. Croatian Bureau of Statistics, Zagreb. 